\title{
Museum Websites and Museum Visitors: Digital Museum Resources and their Use
}

Paul F. Marty

College of Information

Florida State University

240 Louis Shores Building

Tallahassee, FL 32306-2100, USA

850.644 .5133

850.644 .6253 (fax)

marty@ci.fsu.edu

\begin{abstract}
This article presents results from an exploratory survey (administered to more than 1200 visitors at nine different online museums) that addressed questions about the role of museum websites in the lives of museum visitors. The results provide details about the use of digital museum resources on museum websites, and indicate that the majority of online museum visitors have clear expectations for the interactions that take place between museums and museum websites. The article documents the role digital museum resources play in the lives of museum visitors, and provides strategies for supporting the information needs of all visitors as they use digital museum resources, online and in-house. The lessons learned underscore the importance of taking a visitor-centered approach when developing digital museum resources, and the need for museum researchers and professionals to better understand how new information technologies have changed the way museums visitors approach museums and their resources.
\end{abstract}

\section{Keywords}

Museum websites; museum visitors; digital museum resources; visitor studies.

\section{Notice}

This is the author's version of a work that was accepted for publication in Museum Management and Curatorship. Changes resulting from the publishing process, such as peer review, editing, corrections, structural formatting, and other quality control mechanisms may not be reflected in this document. Changes may have been made to this work since it was submitted for publication. A definitive version was subsequently published in Museum Management and Curatorship, 23 (1), 81-99. http://dx.doi.org/10.1080/09647770701865410 


\section{Introduction}

A proper understanding of how museum visitors use digital museum resources in their daily lives is critical for the success of museums in the information age. As museum professionals cope with the challenges of "being digital" (Hamma 2004b), meeting the information needs of online visitors has become an important part of the museum professional's job (Marty 2004). Over the past decade, the number of online museum visitors has increased significantly, and these changes have posed challenges for museum professionals seeking to understand how the digital museum resources they make available online factor into the daily lives of their online visitors.

Visitor studies have always been important for museum professionals, and numerous researchers have explored the relationships between museums and their visitors, online and in-house (Haley Goldman and Schaller 2004; Falk 1998, 2006; Falk and Dierking 2000; Kravchyna and Hastings 2002; Thomas and Carey 2005). Recently, museum researchers and practitioners have stressed the need to study the use of digital museum resources from a user-centered perspective (Hertzum 1998; Jörgensen 2004; Marty 2007a). In particular, they have called for increased studies of a wider variety of users, including museum visitors and professionals, information providers and consumers, inside and outside the museum (Coburn and Baca 2004; Gilliland-Swetland and White 2004; Marty 2006).

This article builds upon existing research by exploring how online museum visitors use digital museum resources in their everyday lives. It focuses on how museum professionals can use this knowledge to better meet the information needs of their online visitors. It stresses the need to examine the relationships visitors form with museums and museum websites, and how these relationships influence their use of digital museum resources, online and in-house.

The results presented below represent the second half of an exploratory survey that was administered to more than 1200 visitors at nine different online museums and addressed the relationship between museums and museum websites in the lives of museum visitors. The first half of this study (presented in Marty 2007b) detailed the circumstances in which online museum visitors visit museum websites before and after visiting museums, their needs and expectations when visiting museum websites before and after visiting museums, and the extent to which museum websites influence their decision to visit museums. The findings offered positive lessons for museum professionals attempting to encourage a cyclical, complementary relationship where visitors to museum websites are inspired to visit physical museums, and visitors to physical museums are inspired to visit museum websites.

The survey questions reported in this article expand upon these results by asking respondents about the way they use digital museum resources in their daily lives, their interactions with museums and museum websites, and the extent to which they distinguish between online and inhouse museum activities. The article addresses the importance of taking a visitor-centered approach when developing and providing access to digital museum resources. The results of the study help museum researchers and professionals by increasing overall knowledge and understanding about the use of digital museum resources by online museum visitors.

\section{Literature Review}


Unprecedented changes with respect to the use of information resources in museums have transformed the experience of visiting a museum, requiring adaptations for museum professionals and museum visitors, and resulting in new information needs and information policies (Besser 1997; Knell 2003). These changes have affected how all users-museum professionals and visitors - interact with digital museum resources in their everyday lives, either when visiting museums in person, or when using museum resources online (Müller 2002).

\section{Digital libraries, archives, and museums}

These ongoing transformations have been influenced and complicated by the functional convergence of digital museums, libraries, and archives, and the changing information needs and expectations of museum visitors. While traditional distinctions between libraries, archives, and museums remain important, the common problems they face in the information age, especially issues related to digitization and digital curation, have led many to stress themes of convergence and commonality rather than differences in the functional requirements of these organizations.

Rayward (1998) examined how changes from physical to digital media affect the traditional distinctions between information organizations, arguing that increased access to digital resources has led to the functional integration of libraries, museums, and archives. Hedstrom and King (2003) explored how these information organizations have worked together over millennia to preserve and advance the state of human knowledge. These issues have also been the focus of a several recent conferences: the RLG (Research Libraries Group) forum in 2005 examined the commonalities of libraries, archives, and museums (http://digitalarchive.oclc.org/da/ViewObject.jsp?objid=0000070504\&reqid=2711); the RBMS (Rare Books and Manuscripts Section of the Association of College and Research Libraries) conference in 2006 explored the theme "Libraries, Archives, and Museums in the 21st Century: Intersecting Missions, Converging Futures?” (http://www.hrc.utexas.edu/rbms2006/); and the international symposium on Digital Curation in 2007 brought together librarians, archivists, and museum professionals to discuss their common digital curation concerns (http://www.ils.unc.edu/digccurr2007/).

While these groups and individuals may bring different perspectives to their shared problems, they all stress the commonalities of libraries, archives, and museums, as well as the challenges they face together in the digital age (cf. Elings and Waibel 2007; Lynch 2002). It is possible that the functional convergence of digital libraries, archives, and museums has contributed to the changing expectations of all museum users, including museum visitors and professionals, about the information resources museums should provide online and in-house. While the influence of this functional convergence on museum visitors may be debated, a growing number of users of all types now expect digital museums to act more like digital libraries - a situation that puts immense pressure on museum professionals to live up to the changing needs and expectations of their visitors.

\section{Changing needs and expectations}


As museum information resources become more technically complex, and the users of those resources become more information literate, the needs and expectations of visitors become increasingly sophisticated. Users of museum resources are no longer satisfied with limited access to information about museum collections, and many desire twenty-four hour access to museum data, no matter where these data are located, or how the data are organized (Cameron 2003; Hamma 2004a). While the ability to manipulate and manage information resources has long been an important skill for museum professionals, meeting these changing expectations can pose new challenges for museum professionals (Lord and Lord 1997; Orna and Pettitt 1998; Reed and Sledge 1988; Washburn 1984).

Changing ideas about the museum's position as an information service organization have prompted questions about the relationship between museums and information science (HooperGreenhill 1992; Jörgensen 2004; MacDonald 1991; Marty 2006; Roberts 2001). These questions are driven in part by the changing needs of museum visitors, whose expectations about increased access to museum information resources may pose difficult challenges for museum professionals, often requiring them to learn new information management skills and integrate new information technologies into their daily work (Hamma 2004b; Marty 2007a).

Access to digital surrogates (information representations of museum artifacts such as digital images, database records, etc.) has offered users new ways to interact with and manipulate museum information resources (Douma and Henchman 2000; Gillard 2002), and museum professionals must find ways to meet the changing needs and expectations of their visitors. For example, access to digital collections can blur the lines between the traditionally separate activities of collections management and exhibit design. Museum professionals no longer need to maintain one source of data for internal use (e.g., by museum employees) and one source of data for external use (e.g., by museum visitors). As more online exhibits draw data directly from collections management systems, these exhibits can become even more timely and interactive, providing online visitors with instant access to information resources representing the latest knowledge about the museum's collections (Besser 1997).

\section{The use of museum information resources}

New information technologies offer museum professionals new ways of bringing information about their collections directly to their audiences. These information resources are used by many different online museum visitors, from recent visitors interested in learning more about the museum's collections, to academic researchers at distant universities searching for particular objects in the museum's holdings. The wide variety of uses and users of museum information resources makes it critical for museum researchers and professionals to explore the use of museum information resources, in-house and online (Booth 1998; Sarraf 1999). As more museums offer digital resources online, and as the number of online museum visitors increases to be as much as ten times the number of physical visitors, studying the use of digital museum resources becomes particularly important.

Today, museums are developing online collections of digital resources at a rapid pace, despite a critical lack of data about the needs of the intended users of those resources (Cunliffe, Kritou, and Tudhope 2001). The lack of data about the use of digital museum resources is a serious 
concern for museums, as not understanding user needs means it is not possible for museum professionals to know whether they are providing access to digital museum resources in a way that satisfies the needs of their intended users (Hertzum 1998). Museum professionals understand the importance of making their online resources more user-centered, but they frequently cannot do so until more is learned about the needs and expectations of their online visitors (Dyson and Moran 2000; Streten 2000). There is a critical need, therefore, for studies that address questions about how online museum visitors use digital museum resources in their everyday lives.

\section{Research Questions and Methods}

This study presents results from an exploratory survey designed to address the following research question: What role do digital museum resources play in the lives of museum visitors?

Answering this question involved addressing a number of related research questions, including: How likely are museum visitors to make digital museum resources a part of their daily lives? How do online museum visitors use digital museum resources? What do museum visitors see as the major differences between museums and museum websites? When performing common museum activities, do museum visitors have a preference for performing these in the museum versus performing them online?

The methods used to answer these research questions are the same as those described in detail in the first half of this study (Marty 2007b). For the benefit of those readers who have not read the earlier paper, an abbreviated version of the research methodology used is presented here; please refer to Marty (2007b) for details about the study's methods and limitations.

The researcher developed an exploratory online survey that asked respondents about the interactions they have with museums and museum websites, the way they use digital museum resources in their daily lives, and the extent to which they distinguish between online and inhouse museum activities. The survey instrument was intentionally designed to replicate the feel of a structured interview, thereby allowing the study to reap the benefits of both survey and interview methods, while simultaneously minimizing the inherent limitations of online research.

Respondents were asked two questions about their museum and museum website visitation patterns. These questions employed a five-point Likert scale ranging from Very Unlikely to Very Likely, and asked:

- How likely are you to visit a museum and its website repeatedly, visiting the museum when you can, and its website when you cannot?

- How likely are you to visit museum websites in your daily life, independent of planning or returning from a museum visit?

Respondents were asked to indicate how likely they were to use certain kinds of online museum resources in their daily lives. This question employed a five-point Likert scale ranging from Very Unlikely to Very Likely, and listed the following online resources:

- Online images of artifacts / collections data

- Online tours of galleries / interactive exhibits 
- Online educational activities / learning resources

- Online research materials / archives

Respondents were asked to indicate the extent to which they agreed with a list of statements about their attitudes and expectations concerning museums and museum websites. This question employed a five-point Likert scale ranging from Strongly Disagree to Strongly Agree, and listed the following statements:

- As best as possible, museum websites should offer the same information, resources, and activities as are available in museums.

- Museum websites should take advantage of the online environment to present unique experiences that cannot be duplicated in museums.

- Museum websites should offer interfaces that can be customized to meet the needs of different online visitors, such as virtual tours that adapt to individual interests.

- Museum websites should offer interfaces that can store personalized information for different online visitors, such as digital collections of favorite museum artifacts.

- When looking for information, it is possible for a visit to a museum's website to substitute for a visit to that museum.

- When viewing artifacts or exhibits, it is possible for a visit to a museum's website to substitute for a visit to that museum.

- My needs and expectations when visiting museum websites are different from my needs and expectations when visiting museums.

- There are some things I prefer to do in museums and some things I prefer to do using museum websites.

Respondents were asked to indicate the extent to which they agreed with a list of statements about their attitudes and expectations concerning the use of museum information resources. This question also employed a five-point Likert scale ranging from Strongly Disagree to Strongly Agree, and listed the following statements:

- When visiting a museum, I usually pick up the available maps, flyers, brochures, gallery guides, etc.

- When leaving a museum, I usually take away the available maps, flyers, brochures, gallery guides, etc. (if allowed).

- After leaving a museum, I expect to be able to find the museum's website easily.

- When away from a museum, I rely on the museum's website to answer questions I have about the museum.

Respondents were asked to indicate whether they prefer to be in the museum or on the museum's website when performing certain common museum activities. This question employed a fivepoint Likert scale ranging from Strongly Prefer Website to Strongly Prefer Museum, and listed the following activities: 
- View artifacts / collections

- Tour galleries / exhibits

- Engage in educational activities / use learning resources

- Access research materials / archives

- Learn about hours of operation / location / directions

- Learn about admission fees / pricing

- Learn about museum facilities / gift shop / restaurants

- Learn about current and future exhibits

- Learn about programs / tours / special events

- Learn about employment/volunteer opportunities

- Learn about donation / membership opportunities

To determine the types of museum visitors who participated in the study, respondents were asked several demographics questions:

- How frequently do you visit museums?

- How frequently do you visit museum websites?

- From your perspective, how important is it for a museum to have a museum website?

The survey was advertised on the following museum websites:

- the Fine Arts Museums of San Francisco (http://www.famsf.org/);

- the Science Museum of Minnesota (http://www.smm.org/);

- the Australia War Memorial Museum (http://www.awm.gov.au/);

- the Victoria and Albert Museum (http://www.vam.ac.uk/);

- the National Museum of Wildlife Art (http://www.wildlifeart.org/);

- the Fruitlands Museum (http://www.fruitlands.org/);

- the Royal Armouries (http://www.royalarmouries.org/);

- the Art Complex Museum (http://www.artcomplex.org/); and

- the Tryon Palace (http://www.tryonpalace.org/).

The results from the survey were processed using SPSS (originally, Statistical Package for the Social Sciences), which generated descriptive statistics for each of the above survey questions. Correlation coefficients (Spearman's rho) and Pearson's chi-squares were also calculated to provide comparative statistics useful for exploring the influence of the type of museum and the type of museum visitor on the use of digital museum resources in the everyday lives of online museum visitors.

\section{Limitations}


The use of exploratory survey methods has limitations that directly reflect the difficulties of conducting research and gathering data when using online surveys (Andrews, Nonnecke, and Preece 2003; Couper 2000). Considering the limitations of online research, exploratory survey research, where the survey instrument takes the place of a structured interview schedule, is often the only practical method available when gathering information from online visitors to museum websites (Haley Goldman and Schaller 2004).

In this study, respondents were restricted to people who a) were already visiting museum websites, and b) chose to answer a survey about museums and museum websites. The placement of the survey link and the survey's focus on museum visitation may also have biased the results toward online visitors planning museum visits (see Marty 2007b for a more detailed discussion of these limitations). While these restrictions place limitations on the generalizability of this research to museum visitors overall, the following results shine a valuable light on the mindset of online museum visitors as a distinct and important research population.

\section{Results}

The online survey was administered from October 2005 to October 2006; there were 1215 valid responses to the survey (out of 1464 total responses) during this time period. For the purposes of this study, survey responses were considered valid if respondents answered at least one question other than the demographics questions. Not every respondent provided a response to every question, and therefore specific numbers of responses are presented for each result below, and the missing responses were factored out of the comparative analyses performed.

\section{Respondent characteristics}

Each of the 1215 respondents who completed the online survey was directed to the study from one of nine different museums. $422(34.7 \%)$ respondents originated from the Australia War Memorial Museum, 353 (29.1\%) from the Fine Arts Museums of San Francisco, 282 (23.2\%) from the Victoria and Albert Museum, 51 (4.2\%) from the Royal Armouries, 41 (3.4\%) from the Science Museum of Minnesota, 29 (2.4\%) from the National Museum of Wildlife Art, 16 (1.3\%) from the Tryon Palace, 12 (1.0\%) from the Fruitlands Museum, and $9(0.7 \%)$ from the Art Complex Museum $(n=1215)$. The inherent unreliability of web metrics and page view statistics for determining visitation rates (Sen, Dacin, and Pattichis 2006), combined with the inability to know whether any given visitor to the website actually saw the link to the survey, makes it impossible to provide any reliable data about survey response rates beyond this distribution of respondents.

As part of the survey, the respondents were asked to answer several questions related to the visitors' general attitudes toward and experiences with museums and museum websites. Their answers to these questions provide some indication of the types of interactions the online museum visitors who responded to this survey have with museums and museum websites: 
- When asked "How frequently do you visit museums?", 13.5\% (163) responded Rarely, 16.4\% (197) Annually, 30.5\% (367) Quarterly, 27.8\% (335) Monthly, 8.9\% (107) Weekly, and $2.9 \%$ (35) Daily (n=1204).

- When asked "How frequently do you visit museum websites?", 12.3\% (147) responded Rarely, 4.8\% (57) Annually, 14.9\% (179) Quarterly, 28.4\% (341) Monthly, 30.5\% (366) Weekly, and 9.2\% (110) Daily ( $\mathrm{n}=1200)$.

- When asked "From your perspective, how important is it for a museum to have a museum website?", 4.4\% (53) responded Very Unimportant, $0.2 \%$ (3) Unimportant, 4.0\% (48) Neutral, 22.0\% (264) Important, and 69.4\% (834) Very Important ( $\mathrm{n}=1202)$.

The typical online museum visitor completing this online survey, therefore, visits museums approximately four times a year, visits museum websites approximately once a week, and considers it very important for museums to have museum websites.

\section{Descriptive statistics}

Table 1 shows the summary of responses provided when respondents were asked about their museum and museum website visitation patterns. According to the results, the majority of online museum visitors are likely or very likely to make visits to museums and museum websites a part of their daily lives. $75 \%$ of survey respondents were either likely or very likely to visit a museum and its website repeatedly, visiting the museum when they can, and its website when they cannot. Similarly, $64.6 \%$ of survey respondents were either likely or very likely to visit museum websites in their daily lives, independent of planning or returning from a museum visit.

\section{[INSERT TABLE 1]}

Table 2 shows the summary of responses provided when respondents were asked how likely they were to use certain kinds of online museum resources in their daily lives. According to the results, online museum visitors are likely to use most types of online museum resources, especially online images and research materials. $64.1 \%$ of survey respondents were either likely or very likely to use online images of artifacts/collections data in their daily lives; $45 \%$ of survey respondents were either likely or very likely to use online tours of galleries/interactive exhibits in their daily lives; $49.3 \%$ of survey respondents were either likely or very likely to use online educational activities/learning resources in their daily lives; and $62.4 \%$ of survey respondents were either likely or very likely to use online research materials/archives in their daily lives.

\section{[INSERT TABLE 2]}

Table 3 shows the summary of responses provided when respondents were asked to indicate the extent to which they agreed with a list of statements about their attitudes and expectations concerning museums and museum websites. According to the results, most online museum visitors have very different expectations for museums and museum websites. For example, while $62.3 \%$ of survey respondents agreed or strongly agreed that museum websites should offer the same information, resources, and activities as are available in museums, $75.6 \%$ of survey 
respondents also agreed or strongly agreed that museum websites should take advantage of the online environment to present unique experiences that cannot be duplicated in museums. Survey respondents were generally in favor of museum websites that can be customized or personalized for different online visitors, although they were more interested in customization (e.g. providing virtual tours that adapt to individual interests) than personalization (e.g. creating personal digital collections of favorite museum artifacts) technologies: $66.3 \%$ agreed or strongly agreed that museum websites should offer interfaces that can be customized to meet the needs of different online visitors, while only $43.2 \%$ agreed or strongly agreed that museum websites should offer interfaces that can store personalized information for different online visitors.

Survey respondents expressed very clear opinions about the possibility for visits to museum websites to substitute for visits to museums: while $40.4 \%$ agreed or strongly agreed that when looking for information, it is possible for a visit to a museum's website to substitute for a visit to that museum, $65.7 \%$ disagreed or strongly disagreed that when viewing artifacts or exhibits, it is possible for a visit to a museum's website to substitute for a visit to that museum. Similarly, according to the results, online museum visitors have very clear preferences for what they want to do on a museum website versus in a museum: $83.9 \%$ agreed or strongly agreed that their needs and expectations when visiting museum websites are different from their needs and expectations when visiting museums, and $84.2 \%$ agreed or strongly agreed that there are some things they prefer to do in museums and some things they prefer to do using museum websites.

\section{[INSERT TABLE 3]}

Table 4 shows the summary of responses provided when respondents were asked to indicate the extent to which they agreed with a list of statements about their attitudes and expectations concerning the use of museum information resources, in the museum or online. According to the results, the vast majority of online museum visitors have a strong positive relationship with museum information resources in that they are frequent users of information resources in museums and they expect museum information resources to be easily accessible online. When visiting a museum, $92.7 \%$ of survey respondents agreed or strongly agreed that they usually pick up the available information resources in house, and $84.4 \%$ agreed or strongly agreed that they take these resources with them when they leave (if permitted). Away from a museum, 90.8\% of survey respondents agreed or strongly agreed that they expect to be able to find the museum's website easily, and $87.4 \%$ agreed or strongly agreed that they rely on the museum's website to answer questions they have about the museum.

\section{[INSERT TABLE 4]}

Table 5 shows the summary of responses provided when respondents were asked to indicate whether they prefer to be in the museum or on the museum's website when performing certain common museum activities. According to the results, online museum visitors have specific preferences for viewing artifacts and exhibits in the museum, and for accessing information on the museum's website. The majority of survey respondents preferred or strongly preferred to be in the museum when viewing artifacts/collections (92.6\%) or touring galleries/exhibits (92.3\%). On the other hand, the majority of survey respondents preferred or strongly preferred to be using 
the museum's website when learning about basic information such as hours of operation, location, and directions (82.4\%), or admission fees and pricing (80.2\%).

While preferences concerning other museum activities were not as pronounced, survey respondents generally preferred to use museum websites when gathering information about museum events or when engaging in activities that may or may not require their physical presence in museums. For instance, $72.6 \%$ preferred or strongly preferred the museum's website when learning about current or future exhibits; $70.5 \%$ preferred or strongly preferred the museum's website when learning about programs, tours, and special events; $63.1 \%$ preferred or strongly preferred the museum's website when accessing research materials and archives; and $61.5 \%$ preferred or strongly preferred the museum's website when learning about museum facilities, gift shops, and restaurants.

For the remaining museum activities, survey respondents were generally split between choices, with many learning toward "no preference." For example, when learning about employment and volunteer opportunities, survey respondents were split between no preference $(43.7 \%)$ and preferring or strongly preferring the museum's website $(50.6 \%)$; similarly, when learning about donation and membership opportunities, survey respondents were split between no preference $(48.5 \%)$ and preferring or strongly preferring the museum's website $(44.3 \%)$. On the other hand, when engaging in educational activities and using learning resources, survey respondents were split into three distinct camps, with $31.3 \%$ preferring or strongly preferring the museum, 33.4\% preferring or strongly preferring the museum's website, and $35.3 \%$ having no preference.

\section{[INSERT TABLE 5]}

\section{Comparative statistics}

A number of comparative analyses were run on the above results, including Spearman's rho and Pearson's chi-squares. The large number of questions asked on this survey meant that thousands of statistical analyses were performed in preparing this article. Given space considerations, it is impossible to present even a small fraction of these analyses, and therefore this section will highlight only the most notable results from the comparative statistics.

An examination of the characteristics of the online museum visitors who completed the survey, and the influence of these characteristics on the survey results, shows that the type of interactions survey respondents have with museums and museum websites have some but no major effects on the role museum websites play in their everyday lives. When comparing survey results with the museum from which the survey respondents originated, for example, the statistical analysis showed no significant correlations based on the museum where respondents found the link for the study (Spearman's rho $<0.05$ in almost all cases).

When comparing survey results with the frequency of museum and museum website visits, the most notable result was the strong correlation (Spearman's rho $=0.48$ ) between the frequency with which respondents visit museums and the frequency with which respondents visit museum websites. The respondents' frequency of museum visits did not, however, correlate strongly with other survey questions, with the highest correlation found between frequency of museum visits 
and the respondents' inclination to strongly prefer museums when touring galleries and exhibits $($ rho $=0.23)$; while significant according to chi-squares tests, the weakness of the correlation ratio suggests that frequency of museum visits is likely not a major factor in determining the relationship online museum visitors have with digital museum resources.

The frequency with which survey respondents visit museum websites, on the other hand, had numerous strong and significant relationships with other survey questions. For example, the frequency with which online visitors visit museum websites was fairly strongly correlated with the importance survey respondents place on museums having museum websites (rho $=0.36$ ), the likelihood they will visit a museum and its website repeatedly, visiting the museum when they can and its website when they cannot (rho $=0.41$ ), the likelihood they will visit museum websites in their daily lives, independent of planning or returning from a museum visit (rho $=$ 0.53), the likelihood they will use online images of artifacts and collections data in their daily lives $($ rho $=0.38)$, and the likelihood they will use online research materials and archives in their daily lives $(\mathrm{rho}=0.38)$. Similarly, the importance survey respondents placed on museums having museum websites correlated fairly strongly with their expectations that after leaving a museum, they will be able to find the museum's website easily ( $\mathrm{rho}=0.31$ ), and their expectations that when away from a museum, they will rely on the museum's website to answer questions they have about the museum $($ rho $=0.33)$.

\section{Discussion}

Within the limitations of the study as described above (cf. Marty 2007b), the results of this survey indicate that online museum visitors, mostly on their own initiative, have developed complicated relationships with digital museums. Not only do the information resources provided by museums and museum websites play important roles in their daily lives, but the users of digital museums are well aware of the critical differences between those resources offered online and in-house. The survey results show that online museum visitors have clear needs and expectations when using digital museum resources in their everyday lives.

Online museum visitors see museums and museum websites as complementary, where one is not likely to replace the other as users search for and access information. They operate within a complicated relationship that governs their use of museum information resources in their daily lives. It is important for everyone interested the use of digital museum resources to embrace and explore this relationship. Only by understanding the nature and extent of the emerging relationship between digital museums and their users can museum researchers and practitioners improve their interactions with all users, inside and outside the museum, including information providers and consumers, museum visitors and professionals.

The results have implications for researchers interested in the role of museums in the information society. Providers of digital museum resources are often more focused on the mechanics of digitizing works of art and cultural heritage than on how people will use those digital resources once they are available. While technical considerations behind the digitization process are important and worthwhile, the individuals determining the content of digital collections must be at least as concerned with the potential use of these resources and their potential impact on the future of museums and other cultural heritage institutions. By addressing the intended use of 
digital museum resources by online museum visitors, this study can help museum professionals make informed decisions that will promote a healthy future for digital museums.

Naturally, emphasizing the actual and intended use of digital museum resources does not minimize the importance of addressing the technical considerations of information organization

and access. Research on museum content management and metadata standards remains important, and progress has already been made by a number of organizations, such as the Getty Research Institute. Technical issues of data aggregation and access have also been studied by researchers from many university and museum collaborations (Cole 2003; Perkins 2001). While such projects have advanced the state-of-the-art in digitization techniques and made it easier for content providers to produce and provide access to digital museum resources, they have not necessarily focused on the questions of why and how people use digital museum resources.

The results of this study help museum researchers and professionals interested in the use of digital museum resources by online museum visitors. It is important for museum professionals to capitalize on the distinct preferences and expectations of online museum visitors if they are to support the changing information needs of the users of their information resources. This discussion concludes, therefore, with three takeaway lessons about the current state of digital museum resources and their use.

\section{Importance of digital museum resources in the lives of users}

Users of digital museums are already making museums, museum websites, and digital museum resources an important part of their daily lives. Online museum visitors are likely to make frequent visits to museums and museum websites, including visits to museum websites independent of planning or returning from museum visits. They are also likely to use a wide variety of digital museum resources in their daily lives, including online images of artifacts and online research materials.

While these findings represent good news for museum professionals interested in promoting the use of digital museum resources, it is important to note that online museum visitors are developing these relationships mostly on their own initiative; the online museum visitors themselves decide whether any given museum or museum website is important to them. It is important for museum professionals to identify and support positive, complementary relationships between their museums and their visitors.

\section{Attitudes and expectations about museums and museum websites}

Users of digital museums have clear attitudes and expectations concerning museums and museum websites, and the use of museum information resources in their daily lives. Survey respondents stated that their use of digital museum resources depends heavily on the close integration of virtual and physical environments. Museum professionals must make it easy for their visitors to locate and use information resources on their websites because the majority of online museum visitors rely on museum websites as an important source of information when away from museums. It is important for museum professionals to promote their museums' websites before, during, and after museum visits. 
Survey respondents also provided overwhelming evidence that their needs and expectations when using museum websites are different from their needs and expectations when visiting museums, and it is important that museum professionals understand these differences in order to improve relationships between digital museums and their users. Developers of museum websites should take advantage of the online environment to offer unique experiences that cannot be duplicated in physical museums, including customization and personalization technologies.

The unique ability of museums to offer their visitors experiences as well as information provides a valuable opportunity for website developers to meet needs by developing dynamic experiences that will attract a wide variety of online visitors and draw them into the museum. The finding that online museum visitors are interested in having access to unique experiences that cannot be duplicated in museums raises important questions about what exactly visitors want by way of these unique experiences. Answering these questions will provide an excellent opportunity for future research into the function of museums in the information society and how museum professionals can take advantage of new information technologies to better serve their visitors.

\section{Preferences for interactions with museum information resources}

Users of digital museums have very specific preferences about their interactions with museum information resources, online and in-house. Online museum visitors have strong opinions about what they want to do online and what they want to do in person when visiting museums, and it is important for museum professionals to understand those differences so they can use them to their advantage. If museum visitors want to purchase tickets online or plan future visits online, then they should be encouraged to do so, especially since this will enable these same visitors to maximize their time viewing artifacts and touring galleries in the museum.

By understanding visitor preferences for online and in-house activities, museum professionals can push tasks that do not require a physical presence to their websites, thereby freeing up as much visitor time as possible during in-person visits. When the results of this study are taken into consideration, one sees that worrying about online visitors not coming to museums in person is less relevant than worrying about the importance of knowing visitor preferences for online versus in-person museum activities. Only when those preferences are identified and evaluated can museum professionals ensure they are developing websites that meet those preferences, and integrating their websites into their museums in ways that supports the needs of their visitors.

As important as these lessons are, the most valuable lesson of this research is the need for more studies that explore the use of digital museum resources in the daily lives of museum visitors. It is important to remember that the vast majority of the world's art and cultural heritage resources resides in the hands of museums, historical societies, community heritage associations, and other information organizations that are only now beginning the process of planning the digitization of their collections (Institute of Museum and Library Services 2005). If the professionals who work in these organizations do not understand and cannot explain how people will use the digital resources they create, what good does it do them to create those same resources? If museum researchers and practitioners are truly to create a sustainable future for digital museums, it is 
important to improve the overall understanding of how museum visitors, online and in-house, use digital museum resources as an integral part of their everyday lives.

\section{Conclusions}

The results of this study offer lessons for museum researchers and professionals interested in understanding and encouraging a positive relationship between museums and their users. Online museum visitors are incorporating digital museum resources into their lives on their own initiative, have strong opinions about the role of digital museums overall, and are interested in creating relationships where museums, museum websites, and museum information resources feature prominently in their daily lives. These lessons underscore the importance of taking a visitor-centered approach when interacting with museum visitors, online or in-house.

As the developers of digital museums look forward through the 21 st century, they can use the results of this and related research projects to improve their understanding of the role digital museum resources play in the lives of museum visitors. Museum professionals can offer information resources uniquely designed for the needs, attitudes, and expectations of online visitors making digital museums part of their everyday lives. By studying the use of digital museum resources, researchers can devise strategies that support the changing information needs of all who use museum information resources.

\section{Acknowledgements}

The author would like to acknowledge the assistance of the museum professionals who promoted this study by linking to the online survey from their museums' websites; without their assistance, this project would never have reached such an international and broad range of online museum visitors. The author would also like to acknowledge the contributions of the anonymous reviewers whose suggestions helped to improve this manuscript.

\section{References}

Andrews, D., B. Nonnecke, and J. Preece. 2003. Electronic survey methodology: A case study in reaching hard to involve Internet users. International Journal of Human-Computer Interaction 16 (2): 185-210.

Besser, H. 1997. The transformation of the museum and the way it's perceived. In The wired museum: Emerging technology and changing paradigms, edited by K. Jones-Garmil, 153-170. Washington, D.C.: American Association of Museums.

Booth, B. 1999. Understanding the information needs of visitors to museums. Museum Management and Curatorship 17 (2): 139-157.

Cameron, F. 2003. Digital Futures I: Museum collections, digital technologies, and the cultural construction of knowledge. Curator 46: 325-340. 
Coburn, E. and M. Baca. 2004. Beyond the gallery walls: Tools and methods for leading endusers to collections information. Bulletin of the American Society for Information Science and Technology 30 (5): 14-19.

Cole, T.W. 2003. OAI: Innovations in the sharing of scholarly information. Library Hi Tech 21 (2): $115-117$.

Couper, M.P. 2000. Web-based surveys: A review of issues and approaches. Public Opinion Quarterly 64: 464-494.

Cunliffe, D., E. Kritou, and D. Tudhope. 2001. Usability evaluation for museum Web sites. Museum Management and Curatorship 19: 229-252.

Douma, M. and M. Henchman. 2000. Bringing the object to the viewer: Multimedia techniques for the scientific study of art. In Museums and the Web 2000, edited by D. Bearman and J. Trant, 59-64. Pittsburgh, PA: Archives \& Museum Informatics. Available from http://www.archimuse.com/mw2000/papers/doumahenchman/doumahenchman.html

Dyson, M. and K. Moran. 2000. Informing the design of Web interfaces to museum collections. Museum Management and Curatorship 18: 391-406.

Elings, M.W. and G. Waibel. 2007. Metadata for all: Descriptive standards and metadata sharing across libraries, archives and museums. First Monday 12 (3): http://firstmonday.org/issues/issue12_3/elings/index.html

Falk, J. H. 1998. Visitors: Who does, who doesn't and why. Museum News 77 (2): 38-43.

Falk, J.H. 2006. The impact of visit motivation on learning: Using identity as a construct to understand the visitor experience. Curator 49 (2): 151-166.

Falk, J.H. and L.D. Dierking. 2000. Learning from museums: Visitor experiences and the making of meaning. Walnut Creek, CA: AltaMira Press.

Gillard, P. 2002. Cruising through History Wired. In Museums and the Web 2002, edited by D. Bearman and J. Trant. Pittsburgh, PA: Archives \& Museum Informatics. Available from http://www.archimuse.com/mw2002/papers/gillard/gillard.html

Gilliland-Swetland, A., and L. White. 2004. Museum information professionals as providers and users of online resources. Bulletin of the American Society for Information Science and Technology 30 (5): 23-27.

Haley Goldman, K. and D. Schaller. 2004. Exploring motivational factors and visitor satisfaction in on-line museum visits. In Museums and the Web 2004, edited by D. Bearman and J. Trant, 223-235. Toronto, CA: Archives and Museum Informatics. Available from http://www.archimuse.com/mw2004/papers/haleyGoldman/haleyGoldman.html 
Hamma, K. 2004a. The role of museums in online teaching, learning, and research. First Monday 9 (5): http://firstmonday.org/issues/issue9_5/hamma

Hamma, K. 2004b. Becoming digital. Bulletin of the American Society for Information Science and Technology 30 (5): 11-13.

Hedstrom, M. and J.L. King. 2003. On the LAM: Library, archive, and museum collections in the creation and maintenance of knowledge communities. Paris, France: Organisation for Economic Co-operation and Development. Available from http://www.oecd.org/dataoecd/59/63/32126054.pdf

Hertzum, M. 1998. A review of museum websites: in search of user-centered design. Archives and Museum Informatics 12: 127-138.

Hooper-Greenhill, E. 1992. Museums and the shaping of knowledge. London: Routledge.

Institute of Museum and Library Services. 2005. Status of technology and digitization in the nation's museums and libraries. Available from http://www.imls.gov/resources/TechDig05/

Jörgensen, C. 2004. Unlocking the museum: A manifesto. Journal of the American Society for Information Science and Technology 55: 462-464.

Knell, S. 2003. The shape of things to come: Museums in the technological landscape. Museum and Society 1 (3): 132-146.

Kravchyna, V. and S. Hastings. 2002. Informational value of museum web sites. First Monday 7 (2): http://www.firstmonday.org/issues/issue7_2/kravchyna

Lord, B., and Lord, G.D. 1997. The manual of museum management. Walnut Creek, CA: Altamira Press.

Lynch, C. 2002. Digital collections, digital libraries, and the digitization of cultural heritage information. First Monday 7 (5): http://www.firstmonday.org/issues/issue7_5/lynch

MacDonald, G.F. 1991. The museum as information utility. Museum Management and Curatorship 10: 305-311.

Marty, P.F. 2004. The evolving roles of information professionals in museums. Bulletin of the American Society for Information Science and Technology 30 (5): 20-23.

Marty, P.F. 2006. Meeting user needs in the modern museum: Profiles of the new museum information professional. Library \& Information Science Research 28 (1): 128-144.

Marty, P.F. 2007a. The changing nature of information work in museums. Journal of the American Society for Information Science and Technology 58 (1): 97-107. 
Marty, P.F. 2007b. Museum websites and museum visitors: Before and after the museum visit. Museum Management and Curatorship 22 (4): 337-360.

Müller, K. 2002. Museums and virtuality. Curator 45 (1): 21-33.

Orna, E., and C. Pettitt. 1998. Information management in museums. Aldershot: Gower.

Perkins, J. 2001. A new way of making cultural information resources visible on the Web: Museums and the open archive initiative. In Museums and the Web 2001, edited by D. Bearman and J. Trant, 87-92. Pittsburgh, PA: Archives and Museum Informatics. Available from http://www.archimuse.com/mw2001/papers/perkins/perkins.html

Rayward, W.B. 1998. Electronic information and the functional integration of libraries, museums and archives. In History and electronic artefacts, edited by E. Higgs, 207-224. Oxford: Oxford University Press.

Reed, P.A., and J. Sledge. 1988. Thinking about museum information. Library Trends 37: 220231.

Roberts, A. 2001. The changing role of information professionals in museums. mda Information 5 (3): 15-18.

Sarraf, S. 1999. A survey of museums on the web: Who uses museum websites? Curator 42: 231-243.

Sen, A., P. Dacin, and C. Pattichis. 2006. Current trends in web data analysis. Communications of the ACM 49 (11): 85-91.

Streten, K. 2000. Honored guests: Towards a visitor centered web experience. In Museums and the Web 2000, edited by D. Bearman and J. Trant. Pittsburgh, PA: Archives and Museum Informatics. Available from http://www .archimuse.com/mw2000/papers/streten/streten.html

Thomas, W.A. and S. Carey. 2005. Actual/virtual visits: What are the links? In Museums and the Web 2005, edited by D. Bearman and J. Trant. Toronto, CA: Archives and Museum Informatics. Available from http://www.archimuse.com/mw2005/papers/thomas/thomas.html

Washburn, W. 1984. Collecting information, not objects. Museum News 63: 5-15.

\section{About the Author}

Paul F. Marty is Assistant Professor in the College of Information at Florida State University. He has a background in ancient history and computer science engineering, and his Ph.D. is from the 
Graduate School of Library and Information Science at the University of Illinois at UrbanaChampaign. Before arriving at FSU, he was Director of Information Technology at the University of Illinois' Spurlock Museum. His current research focuses on the evolution of sociotechnical systems and collaborative work practices in museums, the usability of museum websites, the evolving roles of information professionals in museums, and the digital museum in the life of the user. 


\begin{tabular}{|l|c|c|c|c|c|c|}
\hline & $\begin{array}{c}\text { Very } \\
\text { Unlikely }\end{array}$ & Unlikely & Neutral & Likely & $\begin{array}{c}\text { Very } \\
\text { Likely }\end{array}$ & n \\
\hline $\begin{array}{l}\text { How likely are you to visit a museum } \\
\text { and its website repeatedly, visiting the } \\
\text { museum when you can, and its website } \\
\text { when you cannot? }\end{array}$ & $\begin{array}{c}3.1 \% \\
(31)\end{array}$ & $\begin{array}{c}5.6 \% \\
(56)\end{array}$ & $\begin{array}{c}16.4 \% \\
(165)\end{array}$ & $\begin{array}{c}40.9 \% \\
(412)\end{array}$ & $\begin{array}{c}34.1 \% \\
(343)\end{array}$ & 1007 \\
\hline $\begin{array}{l}\text { How likely are you to visit museum } \\
\text { websites in your daily life, independent } \\
\text { of planning or returning from a } \\
\text { museum visit? }\end{array}$ & $\begin{array}{c}4.5 \% \\
(45)\end{array}$ & $\begin{array}{c}11.9 \% \\
(119)\end{array}$ & $\begin{array}{c}19.0 \% \\
(191)\end{array}$ & $\begin{array}{c}38.1 \% \\
(383)\end{array}$ & $\begin{array}{c}26.5 \% \\
(266)\end{array}$ & 1004 \\
\hline
\end{tabular}

Table 1: Museum and museum website visitation patterns

\begin{tabular}{|l|c|c|c|c|c|c|}
\hline $\begin{array}{l}\text { How likely are you to use each of the } \\
\text { following kinds of online museum } \\
\text { resources in your daily life? }\end{array}$ & $\begin{array}{c}\text { Very } \\
\text { Unlikely }\end{array}$ & Unlikely & Neutral & Likely & $\begin{array}{c}\text { Very } \\
\text { Likely }\end{array}$ & n \\
\hline $\begin{array}{l}\text { Online images of artifacts / collections } \\
\text { data }\end{array}$ & $\begin{array}{c}6.3 \% \\
(64)\end{array}$ & $\begin{array}{c}13.2 \% \\
(133)\end{array}$ & $\begin{array}{c}16.4 \% \\
(165)\end{array}$ & $\begin{array}{c}34.2 \% \\
(345)\end{array}$ & $\begin{array}{c}29.9 \% \\
(302)\end{array}$ & 1009 \\
\hline $\begin{array}{l}\text { Online tours of galleries / interactive } \\
\text { exhibits }\end{array}$ & $\begin{array}{c}8.6 \% \\
(86)\end{array}$ & $\begin{array}{c}19.7 \% \\
(198)\end{array}$ & $\begin{array}{c}26.7 \% \\
(268)\end{array}$ & $\begin{array}{c}30.3 \% \\
(304)\end{array}$ & $\begin{array}{c}14.7 \% \\
(147)\end{array}$ & 1003 \\
\hline $\begin{array}{l}\text { Online educational activities / learning } \\
\text { resources }\end{array}$ & $\begin{array}{c}7.0 \% \\
(70)\end{array}$ & $\begin{array}{c}16.9 \% \\
(169)\end{array}$ & $\begin{array}{c}26.8 \% \\
(268)\end{array}$ & $\begin{array}{c}32.3 \% \\
(323)\end{array}$ & $\begin{array}{c}17.0 \% \\
(170)\end{array}$ & 1000 \\
\hline Online research materials / archives & $\begin{array}{c}5.2 \% \\
(52)\end{array}$ & $\begin{array}{c}12.2 \% \\
(122)\end{array}$ & $\begin{array}{c}20.2 \% \\
(202)\end{array}$ & $\begin{array}{c}29.7 \% \\
(297)\end{array}$ & $\begin{array}{c}32.7 \% \\
(327)\end{array}$ & 1000 \\
\hline
\end{tabular}

Table 2: Use of online museum resources in daily life 


\begin{tabular}{|c|c|c|c|c|c|c|}
\hline $\begin{array}{l}\text { To what extent do you agree with } \\
\text { each of the following statements? }\end{array}$ & $\begin{array}{l}\text { Strongly } \\
\text { Disagree }\end{array}$ & Disagree & Neutral & Agree & $\begin{array}{l}\text { Strongly } \\
\text { Agree }\end{array}$ & n \\
\hline $\begin{array}{l}\text { As best as possible, museum } \\
\text { websites should offer the same } \\
\text { information, resources, and activities } \\
\text { as are available in museums. }\end{array}$ & $2.6 \%(28)$ & $\begin{array}{c}17.3 \% \\
(185)\end{array}$ & $\begin{array}{c}17.8 \% \\
(191)\end{array}$ & $\begin{array}{c}36.8 \% \\
(395)\end{array}$ & $\begin{array}{c}25.5 \% \\
(273)\end{array}$ & 1072 \\
\hline $\begin{array}{l}\text { Museum websites should take } \\
\text { advantage of the online environment } \\
\text { to present unique experiences that } \\
\text { cannot be duplicated in museums. }\end{array}$ & $1.4 \%(15)$ & $5.3 \%(57)$ & $\begin{array}{c}17.6 \% \\
(188)\end{array}$ & $\begin{array}{c}36.6 \% \\
(390)\end{array}$ & $\begin{array}{c}39.0 \% \\
(416)\end{array}$ & 1066 \\
\hline $\begin{array}{l}\text { Museum websites should offer } \\
\text { interfaces that can be customized to } \\
\text { meet the needs of different online } \\
\text { visitors, such as virtual tours that } \\
\text { adapt to individual interests. }\end{array}$ & $1.0 \%(11)$ & $5.0 \%$ & $\begin{array}{c}27.7 \% \\
(295)\end{array}$ & $\begin{array}{c}39.5 \% \\
(420)\end{array}$ & $\begin{array}{c}26.8 \% \\
(285)\end{array}$ & 1064 \\
\hline $\begin{array}{l}\text { Museum websites should offer } \\
\text { interfaces that can store personalized } \\
\text { information for different online } \\
\text { visitors, such as digital collections of } \\
\text { favorite museum artifacts. }\end{array}$ & $3.0 \%(32)$ & $\begin{array}{c}12.9 \% \\
(137)\end{array}$ & $\begin{array}{c}40.9 \% \\
(435)\end{array}$ & $\begin{array}{c}25.2 \% \\
(268)\end{array}$ & $\begin{array}{c}18.0 \% \\
(192)\end{array}$ & 1064 \\
\hline $\begin{array}{l}\text { When looking for information, it is } \\
\text { possible for a visit to a museum's } \\
\text { website to substitute for a visit to } \\
\text { that museum. }\end{array}$ & $\begin{array}{c}17.8 \% \\
(190)\end{array}$ & $\begin{array}{c}23.8 \% \\
(254)\end{array}$ & $\begin{array}{c}17.8 \% \\
(190)\end{array}$ & $\begin{array}{c}25.8 \% \\
(275)\end{array}$ & $\begin{array}{c}14.6 \% \\
(156)\end{array}$ & 1065 \\
\hline $\begin{array}{l}\text { When viewing artifacts or exhibits, } \\
\text { it is possible for a visit to a } \\
\text { museum's website to substitute for a } \\
\text { visit to that museum. }\end{array}$ & $\begin{array}{c}30.9 \% \\
(328)\end{array}$ & $\begin{array}{c}34.8 \% \\
(369)\end{array}$ & $\begin{array}{c}14.7 \% \\
(156)\end{array}$ & $\begin{array}{c}12.0 \% \\
(127)\end{array}$ & $7.6 \%(81)$ & 1061 \\
\hline $\begin{array}{l}\text { My needs and expectations when } \\
\text { visiting museum websites are } \\
\text { different from my needs and } \\
\text { expectations when visiting } \\
\text { museums. }\end{array}$ & $1.8 \%$ (19) & $3.1 \%(33)$ & $\begin{array}{c}11.2 \% \\
(119)\end{array}$ & $\begin{array}{c}39.4 \% \\
(420)\end{array}$ & $\begin{array}{c}44.5 \% \\
(474)\end{array}$ & 1065 \\
\hline $\begin{array}{l}\text { There are some things I prefer to do } \\
\text { in museums and some things I prefer } \\
\text { to do using museum websites. }\end{array}$ & $1.3 \%(14)$ & $2.2 \%(23)$ & $\begin{array}{c}12.3 \% \\
(130)\end{array}$ & $\begin{array}{c}38.5 \% \\
(409)\end{array}$ & $\begin{array}{c}45.7 \% \\
(485)\end{array}$ & 1061 \\
\hline
\end{tabular}

Table 3: Attitudes and expectations concerning museums and museum websites 


\begin{tabular}{|l|c|c|c|c|c|c|}
\hline $\begin{array}{l}\text { To what extent do you agree with } \\
\text { each of the following statements? }\end{array}$ & $\begin{array}{l}\text { Strongly } \\
\text { Disagree }\end{array}$ & Disagree & Neutral & Agree & $\begin{array}{c}\text { Strongly } \\
\text { Agree }\end{array}$ & n \\
\hline $\begin{array}{l}\text { When visiting a museum, I usually } \\
\text { pick up the available maps, flyers, } \\
\text { brochures, gallery guides, etc. }\end{array}$ & $1.2 \%(12)$ & $1.8 \%(18)$ & $\begin{array}{c}4.4 \% \\
(44)\end{array}$ & $\begin{array}{c}36.1 \% \\
(364)\end{array}$ & $\begin{array}{c}56.6 \% \\
(571)\end{array}$ & 1009 \\
\hline $\begin{array}{l}\text { When leaving a museum, I usually } \\
\text { take away the available maps, flyers, } \\
\text { brochures, gallery guides, etc. (if } \\
\text { allowed). }\end{array}$ & $2.3 \%(23)$ & $6.0 \%(60)$ & $\begin{array}{c}7.3 \% \\
(74)\end{array}$ & $\begin{array}{c}35.1 \% \\
(354)\end{array}$ & $\begin{array}{c}49.3 \% \\
(497)\end{array}$ & 1008 \\
\hline $\begin{array}{l}\text { After leaving a museum, I expect to } \\
\text { be able to find the museum's } \\
\text { website easily. }\end{array}$ & $1.0 \%(10)$ & $0.8 \%(8)$ & $\begin{array}{c}7.4 \% \\
(74)\end{array}$ & $\begin{array}{c}33.3 \% \\
(333)\end{array}$ & $\begin{array}{c}57.5 \% \\
(574)\end{array}$ & 999 \\
\hline $\begin{array}{l}\text { When away from a museum, I rely } \\
\text { on the museum's website to answer } \\
\text { questions I have about the museum. }\end{array}$ & $1.2 \%(12)$ & $2.0 \%(20)$ & $\begin{array}{c}9.4 \% \\
(94)\end{array}$ & $\begin{array}{c}32.9 \% \\
(329)\end{array}$ & $\begin{array}{c}54.5 \% \\
(546)\end{array}$ & 1001 \\
\hline
\end{tabular}

Table 4: Attitudes and expectations concerning museum information resources 


\begin{tabular}{|c|c|c|c|c|c|c|}
\hline $\begin{array}{l}\text { When performing each of the } \\
\text { following activities, please indicate } \\
\text { whether you prefer to be in the } \\
\text { museum or using the museum's } \\
\text { website. }\end{array}$ & $\begin{array}{c}\text { Strongly } \\
\text { Prefer } \\
\text { Website }\end{array}$ & $\begin{array}{l}\text { Prefer } \\
\text { Website }\end{array}$ & Neutral & $\begin{array}{c}\text { Prefer } \\
\text { Museum }\end{array}$ & $\begin{array}{c}\text { Strongly } \\
\text { Prefer } \\
\text { Museum }\end{array}$ & $\mathbf{n}$ \\
\hline View artifacts / collections & $\begin{array}{c}1.8 \% \\
(19)\end{array}$ & $\begin{array}{l}1.6 \% \\
(17)\end{array}$ & $\begin{array}{c}4.0 \% \\
(43)\end{array}$ & $\begin{array}{c}22.1 \% \\
(236)\end{array}$ & $\begin{array}{c}70.5 \% \\
(754)\end{array}$ & 1069 \\
\hline Tour galleries / exhibits & $\begin{array}{c}0.9 \% \\
(10)\end{array}$ & $\begin{array}{l}1.5 \% \\
(16)\end{array}$ & $\begin{array}{c}5.2 \% \\
(55)\end{array}$ & $\begin{array}{c}24.3 \% \\
(258)\end{array}$ & $\begin{array}{c}68.0 \% \\
(722)\end{array}$ & 1061 \\
\hline $\begin{array}{l}\text { Engage in educational activities / use } \\
\text { learning resources }\end{array}$ & $\begin{array}{l}8.3 \% \\
(87)\end{array}$ & $\begin{array}{l}25.1 \% \\
(264)\end{array}$ & $\begin{array}{c}35.3 \% \\
(372)\end{array}$ & $\begin{array}{c}17.9 \% \\
(189)\end{array}$ & $\begin{array}{c}13.4 \% \\
(141)\end{array}$ & 1053 \\
\hline Access research materials / archives & $\begin{array}{c}24.2 \% \\
(257)\end{array}$ & $\begin{array}{c}38.9 \% \\
(413)\end{array}$ & $\begin{array}{c}20.6 \% \\
(219)\end{array}$ & $\begin{array}{c}8.3 \% \\
(88)\end{array}$ & $\begin{array}{l}8.1 \% \\
(86)\end{array}$ & 1063 \\
\hline $\begin{array}{l}\text { Learn about hours of operation / } \\
\text { location / directions }\end{array}$ & $\begin{array}{c}44.4 \% \\
(474)\end{array}$ & $\begin{array}{c}38.0 \% \\
(406)\end{array}$ & $\begin{array}{l}10.2 \% \\
(109)\end{array}$ & $\begin{array}{l}1.8 \% \\
(19)\end{array}$ & $\begin{array}{l}5.6 \% \\
(60)\end{array}$ & 1068 \\
\hline Learn about admission fees / pricing & $\begin{array}{c}42.0 \% \\
(448)\end{array}$ & $\begin{array}{c}38.2 \% \\
(408)\end{array}$ & $\begin{array}{l}13.8 \% \\
(147)\end{array}$ & $\begin{array}{l}1.3 \% \\
(14)\end{array}$ & $\begin{array}{l}4.7 \% \\
(50)\end{array}$ & 1067 \\
\hline $\begin{array}{l}\text { Learn about museum facilities / gift } \\
\text { shop / restaurants }\end{array}$ & $\begin{array}{l}27.0 \% \\
(288)\end{array}$ & $\begin{array}{c}34.5 \% \\
(368)\end{array}$ & $\begin{array}{l}28.6 \% \\
(305)\end{array}$ & $\begin{array}{l}4.6 \% \\
(49)\end{array}$ & $\begin{array}{l}5.3 \% \\
(56)\end{array}$ & 1066 \\
\hline $\begin{array}{l}\text { Learn about current and future } \\
\text { exhibits }\end{array}$ & $\begin{array}{c}30.9 \% \\
(328)\end{array}$ & $\begin{array}{r}41.7 \% \\
(443)\end{array}$ & $\begin{array}{l}18.8 \% \\
(200)\end{array}$ & $\begin{array}{l}3.7 \% \\
(39)\end{array}$ & $\begin{array}{l}4.9 \% \\
(52)\end{array}$ & 1062 \\
\hline $\begin{array}{l}\text { Learn about programs / tours / special } \\
\text { events }\end{array}$ & $\begin{array}{l}27.8 \% \\
(294)\end{array}$ & $\begin{array}{c}42.7 \% \\
(451)\end{array}$ & $\begin{array}{l}21.2 \% \\
(224)\end{array}$ & $\begin{array}{l}3.5 \% \\
(37)\end{array}$ & $\begin{array}{c}4.8 \% \\
(51)\end{array}$ & 1057 \\
\hline $\begin{array}{l}\text { Learn about employment / volunteer } \\
\text { opportunities }\end{array}$ & $\begin{array}{l}24.2 \% \\
(257)\end{array}$ & $\begin{array}{l}26.4 \% \\
(280)\end{array}$ & $\begin{array}{c}43.7 \% \\
(463)\end{array}$ & $\begin{array}{c}2.6 \% \\
(28)\end{array}$ & $\begin{array}{c}3.0 \% \\
(32)\end{array}$ & 1060 \\
\hline $\begin{array}{l}\text { Learn about donation / membership } \\
\text { opportunities }\end{array}$ & $\begin{array}{l}16.9 \% \\
(178)\end{array}$ & $\begin{array}{c}27.4 \% \\
(289)\end{array}$ & $\begin{array}{l}48.5 \% \\
(511)\end{array}$ & $\begin{array}{c}4.1 \% \\
(43)\end{array}$ & $\begin{array}{l}3.1 \% \\
(33)\end{array}$ & 1054 \\
\hline
\end{tabular}

Table 5: Preferences for performing activities in museums or on museum websites 